\title{
The Effect of Obstetric Complications (Premature Rupture of Membrans, Pre Eclampsia and Post Date) on the Type of Labor in Mojokasri Hospital
}

\author{
Sugiati, Nurwijayanti, Nurdina \\ Mojokasri Hospital, Mojokerto, \\ Indonesia \\ Email: \\ trisnasugiati@gmail.com
}

\begin{abstract}
Obstetric complications are complications that occur during the pregnancy process or complications that can occur after the mother gives birth, for example, KPD, Bleeding, Abortion, post date, Preeclampsia and Eclampsia and others that can cause risks to the mother and fetus that will affect labor (. The purpose of this study was to determine the effect of obstetric complications (KPD, Pre-eclampsia and Post Date) on the type of labor in Mojokasri Kawaananan, Mojokerto Regency in 2018.

The design used in the study is Comparative. Population were all maternal obstetric complications (KPD, Pre Eklampsi, Post Date) in Mojokasri Hospital in June to August 2018 with a total of 186 people. The sample size is 126 respondents, using the simple random technique. Independent variables are Obstetric Complications (KPD, PEB and Post Date) the dependent variable is Type of Labor (Normal, Action, Sectio Caesarea). Data was collected using observation sheets, then analyzed using the Logistic Regression test. Statistical test results obtained from Kebidanan Complications obtained p value of $0,000<\alpha=0.05$, so that $\mathrm{HO}$ is rejected and $\mathrm{H} 1$ is accepted. This means that the variable midwifery complication affects the type of labor Actions / sectio caesarea in Kawedanan Mojokasri, Mojokerto Regency.
\end{abstract}

Keywords: Premature Rupture of Membrans, Preeclampsia, Postdate, Sectio Caesarea

Received : March 12, 2019

Accepted : October 13, 2019

Published : November 26, 2019

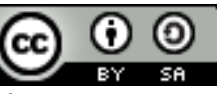

This is an open-acces article distributed under the terms of the Creative Commons Attribution-ShareAlike 4.0 International License. 


\section{INTRODUCTION}

Obstetric complications are complications that occur during the pregnancy process or complications that can occur after the mother gives birth, for example, KPD, Bleeding, Abortion, Long Partus, Preeclampsia and Eclampsia and others that can cause risks to the mother and fetus which will affect labor. Complications during pregnancy can also affect labor, if labor is carried out spontaneously with mothers who have complications of pregnancy will result in a high enough risk to the mother and her baby.

The World Health Organization (WHO) sets the standard for Sectio caesarea in a country to be around $5-10 \%$ per 1,000 births in the world. Government hospitals are approximately $11 \%$ while private hospitals can be more than 30\% (Hasaneroglu, Murat Bakacak, 2014). According to WHO the increase in labor with Sectio caesarea in all countries during 2007-2008 was 110,000 per birth throughout Asia (Sinha Kounteya, 2012). Other data regarding the national rate of occurrence of labor with Sectio caesarea in Indonesia is around 15.3\% (RI Ministry of Health. 2014). The national rate of pregnancy complications was reported to be $6.3 \%$ and $2.3 \%$ experienced surgery, while $13 \%$ were pregnant women who did not experience complications (RI Ministry of Health. 2016).

From the data obtained in Mojokerto Regency, up to June 2018 the normal labor rate was $63.71 \%$, the Sectio caesarea delivery rate was $34.32 \%$ and labor with $1.97 \%$ action with obstetric complication rates $75.16 \%$ of the target $80 \%$ in 1 year. According to a study conducted in Mojokasri Hospital in June 2018 the number of deliveries was 187 people with normal labor $55.82 \%$, delivery of Sectio caesarea $40.60 \%$, and delivery of Vaccine action $3.58 \%$ with obstetric complication rates $59.36 \%$. There were 111 people with complications of pregnancy including eclampsia Pre $15.32 \%$, old Partus $7.21 \%$, Infection 6.31\%, Post Date 21.62\%, KPD 22.52\%, 8.11\% and Premature 7, 21\% and others $11.71 \%$.

The purpose of this study was to determine the effect of obstetric complications (KPD, Preeclampsia and Post Date) on the type of labor in Mojokasri Kawedanan, Mojokerto Regency in 2018. The design used in the study was Comparative. Population were all maternal obstetric complications (KPD, Pre Eklampsi, Post Date) in Mojokasri Hospital in June to August 2018 with a total of 186 people. The sample size is 126 respondents, using the simple random technique. Independent variables are Obstetric Complications (KPD, PEB and Post Date) the dependent variable is Type of Labor (Normal, Action, Sectio Caesarea). Data was collected using observation sheets, then analyzed using the Logistic Regression test

\section{MATERIALS AND METHODS}

The research design used in this study is comparative, namely research that aims to compare between two groups or more of a particular variable. (Arikunto, 2010). The independent variables in this study were obstetric complications (KPD, preeclampsia and Post Date). Whereas for the dependent variable is Type of Labor (Normal, Action / Sectio Caesarea). The population in this study were all women who had obstetric complications in the KPD, Pre Eklampsi and Post Date in June to August 2018, which were 186 people in Mojokasri. The sample used was part of the mothers who had complications.

Midwifery KPD, Pre Eklampsi and Post Date are in Mojokasri Weddings with 126 people. The study was conducted at Mojokasri Military District, Mojokerto Regency on September 29 to October 15, 2018 in 2018. The data used in this study were secondary data obtained from observation sheets, maternal cohort register books, library results and research journals related to the handling of obstetric emergencies.

\section{RESULT}

Multivariate analysis using Logistic Regression Cross Tabulation Between Midwifery Complications and Types of Labor

Table 1.1 Cross Tabulation Between Obstetric Complications and Types of Labor

\begin{tabular}{rrrrrrrr}
\hline & \multicolumn{4}{c}{ Jenis Persalinan } & \multicolumn{2}{c}{ Total } \\
\hline & \multicolumn{4}{c}{ Normal } & \multicolumn{2}{c}{ Action/SC } & \multicolumn{2}{c}{} \\
\cline { 1 - 6 } KPD & 12 & 9,5 & 38 & $30,2 \%$ & 50 & $39,7 \%$ \\
\hline
\end{tabular}




\begin{tabular}{cccccccc}
\hline Midwifery & PEB & 4 & $3,2 \%$ & 18 & $14,3 \%$ & 22 & $17,5 \%$ \\
\cline { 2 - 8 } Complications & Post Date & 24 & $19,0 \%$ & 30 & $23,8 \%$ & 54 & $42,9 \%$ \\
\hline Total & & 40 & $31,7 \%$ & 86 & $68,3 \%$ & 126 & $100,0 \%$ \\
\hline
\end{tabular}

Based on table 1.1 above, it is known that almost half of the respondents with obstetric complications in the KPD delivered by Sectio Caesarea, 38 respondents (30.2\%).

\section{Multivariate analysis simultaneously.}

Table 1.2 Multivariate analysis simultaneously

Variables in the Equation

\begin{tabular}{|c|c|c|c|c|c|c|c|}
\hline & & B & S.E & Wald & $\mathrm{df}$ & Sig. & $\operatorname{Exp}(B)$ \\
\hline Step 0 & constant &, 765 & ,191 & 15,997 & 1 & ,000 & 2,150 \\
\hline
\end{tabular}

Based on table 1.2 multivariate analysis with Logistic Regression simultaneously shows a significant result of 0,000 .

It can be concluded that all independent variables (premature rupture of membranes, preeclampsia and post date) jointly affect the dependent variable (Type of Action Delivery / SC).

\section{Multivariate Regression Analysis With Cox And Snell R Coefficient, Nagelkerke R Square}

Table 1.3 Multivariate analysis with logistic regression with Cox and Snell R coefficients, Nagelkerke R Square.

\begin{tabular}{cccc}
\hline Step & -2 Log likelihood & Cox\&snel R Square & Nagelkerke R Square \\
\hline 1 & $150,162^{\mathrm{a}}$ &, 056 &, 079 \\
\hline
\end{tabular}

Estimation terminated at iteration number 4 because parameter estimates changed by less than ,001

Based on Table 1.3 above shows Cox and Snell R coefficient of 0.056 or $6 \%$ and Nagelkerke R Square coefficient of 0.079 or $8 \%$. Nagelkerke coefficient of $0.0 \%$ means that the independent variable (premature rupture of membranes, preeclampsia and post date) affects the dependent variable (type of labor) in general by $6 \%$, while $94 \%$ is influenced by the variability of other variables outside the three independent variables studied (KPD, Pre Exploit and Post Date)

\section{Partial Multivariate Analysis}

Table 1.4 Partial multivariate analysis

Variables in the Equation

\begin{tabular}{|c|c|c|c|c|c|c|c|c|c|}
\hline & & \multirow{2}{*}{ B } & \multirow{2}{*}{ S.E. } & \multirow{2}{*}{ Wald } & \multirow{2}{*}{ df } & \multirow{2}{*}{ Sig } & \multirow{2}{*}{$\operatorname{Exp}(B)$} & \multicolumn{2}{|c|}{$95 \%$ C.I.for $\mathrm{EXP}(\mathrm{B})$} \\
\hline & & & & & & & & Lower & Upper \\
\hline \multirow{3}{*}{ Step $1^{\mathrm{a}}$} & KPD & ,930 & ,430 & 4,679 & 1 & ,031 & 2,533 & 2,533 & 1,091 \\
\hline & $\mathrm{PE}$ & 1,281 & ,617 & 4,312 & 1 & ,038 & 3,600 & 3,600 & 1,074 \\
\hline & PD & ,223 & ,274 & ,664 & 1 & ,415 & 1,250 & 1,250 & \\
\hline
\end{tabular}

Variable(s) entered on step 1: KPD, PreEklampsi.

Based on the results of the Logistic Regression analysis partially indicate that: 
1. KPD variable is obtained $\mathrm{p}$ value $0.031<\alpha=0.05$, so $\mathrm{H} 0$ is rejected and $\mathrm{H} 1$ is accepted. It can be concluded that the KPD variable affects the type of labor / Sectio Caesarea.

2. Pre Eklampsi variable obtained $\mathrm{p}$ value $0.038<\alpha=0.05$, so that $\mathrm{H} 0$ is rejected and $\mathrm{H} 1$ is accepted. It can be concluded that the Pre-eclampsia variable affects the type of labor / Sectio Caesarea.

3. Post Date variable obtained $\mathrm{p}$ value $0.415>\alpha=0.05$, so $\mathrm{H} 0$ is accepted and $\mathrm{H} 1$ is rejected. It can be concluded that the Post Date variable does not affect Sectio Caesarea type of labor.

4. The lowest / smallest $p$ value is found in the KPD variable, where the value of $p$ value is $0.031<\alpha=$ 0.05. It can be concluded that Midwifery Complications of KPD are the dominant factors that influence the type of Sectio Caesarea.

\section{DISCUSSION \\ Effect of Obstetric Obstetric Complications on Types of Labor (Normal, Action, Sectio Caesarea) in Kawedanan Mojokasri}

Based on the results of the study, it was found that out of 126 respondents it was known that almost half of the respondents did not have a CDD giving birth by Acting / Sectio Caesarea as many as 48 respondents $(38.1 \%)$. And almost half of the respondents with Complications of Maternal and Childhood Corruption Disease by Acting / Sectio Caesarea were 38 respondents (30.3\%) and from logistic regression tests obtained $\mathrm{p}$ value $0.031<\alpha=0.05$, it can be concluded that Obstetrics complications early rupture membranes affect type of Caesarean / Sectio delivery.

In this study the results (OR: 2.53) showed that maternity women with complications of early rupture of membranes had a chance of 2.53 times to give birth by action / SC. This is in line with previous research conducted by Novianti Sihombing labor complications (OR: 6.63) having a greater chance of delivery by cesarean section.

In this study, researchers assumed that the complications of Midwifery Early Obstetrics had higher rates of emergency due to the complications of chorio amnionitis and asphyxia in the fetus so that they needed more intensive treatment so that the handling of maternal and infant salvation had to be more optimal. childbirth assistance. (Sarma N Lumbanraja. 2017) Each delivery is expected to run normally, namely by vaginal delivery. But in the case of the KPD that took place in Kawedanan Mojokasri, the Sectio Caesarea action was the right and fast action so that it would avoid unwanted things so that the maternal and infant mortality rates could be prevented or could be reduced. Amniosis is a protection for babies.

inside the uterus to maintain survival both from infection and asphyxia. Rupture of the membranes is a danger sign for the mother and baby, especially the infection factor. If an infection occurs in the mother who is marked with heat, this will also affect the baby, the baby will experience infection, asphyxia and even death.

Mother's assistance during pregnancy and childbirth is very important in order to reduce maternal and infant mortality. With the assistance of high-risk pregnant women, it is hoped that pregnant women can be handled well with integrated Anc services and routine ANC, so that they can minimize further complications. In this case, one pregnant woman is accompanied by one pregnant woman cadre, in which the cadre's task is to monitor and deliver the pregnant woman if she needs treatment for her pregnancy. In addition to assisting pregnant women, it is necessary to use the latest technology by using the Whats App group where participants consist of village midwives and all pregnant women in the Kawedanan Mojokasri area, hoping to convey information quickly and pregnant women can consult directly about the state of pregnancy.

\section{Effect of Pre-eclampsia Obstetrics Complications on Types of Labor (Normal, Action, Sectio Caesarea) at Mojokasri Hospital.}

Based on the results of the study it was found that out of 126 respondents it was known that the majority of respondents with Complications other than Pre-eclampsia gave birth by Action / Sectio Caesarea as many as 68 respondents $(54.0 \%)$. And a small proportion of respondents with Pre-eclampsia Maternity Complications by Action / Sectio Caesarea were 18 respondents (14.3\%) and from the results of the Logistic Regression test the Pre Eklampsi variable was obtained p value $0.038<\alpha=0.05$, so it can be concluded that the variable Pre-eclampsia affects the type of labor / Sectio Caesarea.

This is in line with the research conducted by Veibymiaty Sumelung in the medical record of Liun Kendage Regional Hospital in 2013, after fetal distress, and non-advanced delivery, pre eclampsia 
was the third largest indication of 167 respondents as many as 41 respondents (24.55\%) experienced pre eclampsia.

In this study the results (OR: 3,6) showed that the complicating mothers with Pre Eklampsi had a chance of 3.6 times to give birth by action / Sectio Caesarea.

According to the researchers' assumption that it is necessary to take immediate action in handling obstetric complications with preeclampsia, this is because appropriate and rapid action needs to be taken to prevent further complications from occurring. Impending eklampsi is a dangerous threat to the condition of mothers with pre-eclampsia. Sectio caesarean surgery is still the main choice in handling labor assistance. But it does not rule out the possibility of being able to be born normally by handling prevention of further complications. For the prevention of impending eclampsia, it is carried out by administering magnesium sulfate with the appropriate dosage. If the initial action for prevention of seizures can already be done, then the sectio caesarea is considered not necessary.

\section{Effect of Post Date Obstetrics Complications on Types of Labor (Normal, Action, Sectio Caesarea) at Mojokasri Hospital.}

Based on the results of the study it was found that out of 126 respondents it was known that almost half of the respondents with Post Date Maternity Complications by Sectio Caesarea were 26 respondents (48.1\%), and from the logistic regression statistical test the Post Date variable obtained $\mathrm{p}$ value $0.415>\alpha=0,05$, so it can be concluded that the Post Date variable does not affect the type of labor / Sectio Caesarea.

In this study the results (OR: 1.25) showed that maternity women with complications of early rupture of membranes had 1.25 times the chance to deliver with action / Sectio Caesarea.

This is in contrast to Novianti's research on the variables of maternal and fetal health status, the age of the fetus at birth more than 42 weeks (post term) 1.97 times more likely to occur cesarean delivery than the age of birth in 38-42 weeks. With a birth age of $>42$ weeks (OR: 1.97). (Novianti Sihombing * a, Ika Saptarinia, Dwi sisca Kumala Putria, 2013).

In Post Date complications, appropriate relief measures are with sectio caesarea. This is because the length of the baby in the womb causes bigger babies and macrosomia which causes shoulder jam and prolonged labor. Lack of nutrition and oxygen to the baby is also a consideration for delivery by sectio caesarea. (Cuningham F. Gary, Norman F. Gant.Et all. 2010). Because of the many risks of normal delivery management, Caesarea sectio action is still a better choice, so in this study, most respondents with Post Date Complications were delivered by Sectio Caesarea by 25 respondents (59.5\%). This is in order to save the lives of mothers and their babies. So that it can reduce maternal and infant mortality. (Icemi Sukarni, Wahyu. 2015).

However, in a study carried out at the Palace of Mojokasri, that normal labor still occurs in almost half of women with obstetric complications Post Date. This is due to the management of prenatal care and good management of labor so that labor can be carried out normally. This is the goal of saving mothers and babies with safe childbirth care by paying attention to safety factors and reducing complications in the mother and baby.

In this research in Modjokasri early referrals have been made, namely mothers with gestational age 4142 weeks have been referred, so that further complications do not occur and labor is almost half can walk normally.

\section{Dominant Factors Affecting Obstetric Complications in CD on Caesarean / Sectio Labor}

Based on the statistical results with the Logistic Regression test, the lowest / smallest $\mathrm{p}$ value is found in the Early Rupture Amniotic variable, where the value of $p$ value is $0.031<\alpha=0.05$. It can be concluded that the Early Rupture of Amniotic Obstetric Complications is the dominant factor affecting the Type of Caesarean Action / Sectio Labor.

The dominant factor is a factor that has a stronger influence than other factors. The results showed that Early Rupture of Obstetrics Obstetric Complications that had a significant effect on the Types of Sectio Caesarean Delivery in Mojokasri Subdistrict, Mojokerto Regency, were the most influential factors compared to the Pre-eclampsia and Post Date Obstetric Complication Factors for Sectio Caesarean Delivery.

In the research at Mojokasri Medicines, the number of complications of maternal and neonatal KPD by Action / Sectio Caesarea was 38 respondents (76.0\%), this was a very high number. KPD 
obstetric complications occur a lot in mothers in Mojokasri. And the rate of labor with caesarean section is also very high.

Amniosis is a protection for babies in the uterus to maintain survival from both infection and asphyxia. Rupture of the membranes is a danger sign for the mother and baby, especially the infection factor. If an infection occurs in the mother who is marked with heat, this will also affect the baby, the baby will experience infection, asphyxia and even death. (Varney, H., 2011).

In this study, researchers assumed that the complications of Midwifery Early Obstetrics had higher rates of emergency due to the complications of chorio amnionitis and asphyxia in the fetus so that they needed more intensive treatment so that the handling of maternal and infant salvation had to be more optimal. childbirth assistance (Manuaba I.B.G. 2010). Each delivery is expected to run normally, namely by vaginal delivery. But in the case of the KPD that took place in Kawedanan Mojokasri, the Sectio Caesarea action was the right and fast action so that it would avoid unwanted things so that the maternal and infant mortality rates could be prevented or could be reduced. (Mochtar R. 2011).

\section{CONCLUSION}

The most dominant factor that influences is Early Rupture of Obstetrics Obstetrics Complications on Type of Action / Sectio Caesarea in Mojokasri Kawanan, Mojokerto Regency, where the results of the logistic regression test obtained the lowest / lowest $\mathrm{p}$ value $0.031<\alpha=0.05$.

\section{REFERENCES}

Arikunto. (2010). Research procedure: a practical approach, Jakarta: Rineka Cipta.

Cuningham, F. Gary, Norman, F. Gant. Et all. (2010). Williams Obstetric, Twenry-third Edition. McGraw-Hill Companies. United States of America.

Hasaneroglu, Bakacak, M. (2014). Relationship between Premature Rupture of Membrane and Collagen Amount in Chorioamnionic Mambranes in Pregnancy Term, Department of Obstetrics and Ginecology, Turkey.

Sukarni, I., \& Wahyu. (2015). Maternity Nursing Books. Jakarta: Nuha Medika.

RI Ministry of Health. (2014). Ministry of Health Data and Information Center. Jakarta: Indonesian Ministry of Health.

RI Ministry of Health. (2016). Maternal Neonatal Emergency Care. Jakarta: Indonesian Ministry of Health.

Manuaba, I.B.G. (2010). Womb disease and family planning for midwife education. Jakarta: EGC.

Sihombing, N., Saptarinia, I., \& Putria, D. S. K. (2013). Determinants of sectio caesarean deliveries in Indonesia (further analysis of risk data in 2013).

Saifuddin, A. B., Adruaansz, G., Wiknjosastro, G. H., \& Waspodo, D. (2010). National Resource Book for Maternal and Neonatal Health Services. Issue 2. 5th print. Jakarta: Bina Pustaka Foundation Sarwono Prawiryoharjo.

Lumbanraja, S. N. (2017). Obstetric emergencies. Medan: USU PRESS.

Varney, H. (2011). Midwifery Care Textbook Edition 4. Jakarta: EGC 